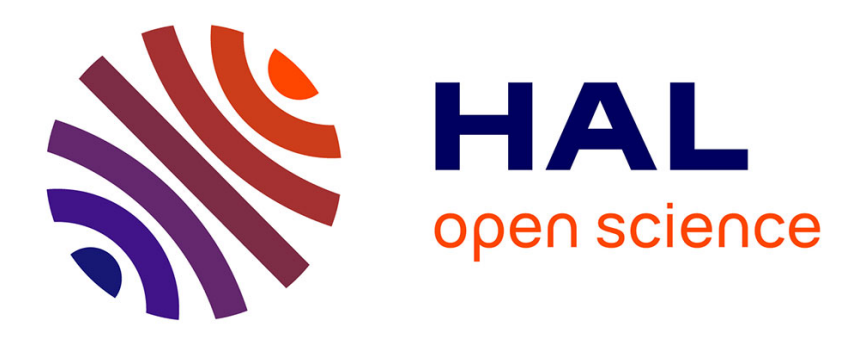

\title{
Aujeszky's disease (pseudorabies) virus: the virus and molecular pathogenesis - State of the art, June 1999
}

Thomas Mettenleiter

\section{To cite this version:}

Thomas Mettenleiter. Aujeszky's disease (pseudorabies) virus: the virus and molecular pathogenesis - State of the art, June 1999. Veterinary Research, 2000, 31 (1), pp.99-115. 10.1051/vetres:2000059 . hal-00902643

\section{HAL Id: hal-00902643 https://hal.science/hal-00902643}

Submitted on 1 Jan 2000

HAL is a multi-disciplinary open access archive for the deposit and dissemination of scientific research documents, whether they are published or not. The documents may come from teaching and research institutions in France or abroad, or from public or private research centers.
L'archive ouverte pluridisciplinaire HAL, est destinée au dépôt et à la diffusion de documents scientifiques de niveau recherche, publiés ou non, émanant des établissements d'enseignement et de recherche français ou étrangers, des laboratoires publics ou privés. 


\title{
Aujeszky's disease (pseudorabies) virus: the virus and molecular pathogenesis - State of the art, June 1999
}

\author{
Thomas C. MetTEnLEITER \\ Institute of Molecular Biology, Friedrich-Loeffler-Institutes, \\ Federal Research Centre for Virus Diseases of Animals, 17498 Insel Riems, Germany
}

\begin{abstract}
Considerable progress has been made during the last years in understanding the molecular basis of protein function in pseudorabies virus (PrV), the causative agent of Aujeszky's disease (AD). Major topics have been the identification and functional characterisation of viral envelope glycoproteins and cellular virus receptors, elucidation of viral proteins involved in neurovirulence and neuropathogenesis, detection and characterisation of attenuating mutations present in and leading to successful attenuated live vaccines, and the near completion of the genomic sequence of PrV DNA. This review, which follows an article prepared for the 1993 AD symposium in Budapest, Hungary, will briefly summarise those recent developments and update the reader on the current state of the art in PrV research.
\end{abstract}

Aujeszky's disease / pseudorabies virus / glycoprotein / molecular pathogenesis / tropism

Résumé - Le virus de la maladie d'Aujeszky : virus et pathogenèse au niveau moléculaire - État des lieux, Juin 1999. Ces dernières années ont donné lieu à des progrès considérables pour la compréhension des bases moléculaires de la fonction des protéines du virus de la maladie d'Aujeszky (VMA). Les principaux sujets d'étude ont été l'identification et la caractérisation fonctionnelle des glycoprotéines d'enveloppe et des récepteurs cellulaires pour le virus, la mise en évidence des protéines virales impliquées dans la neurovirulence et la neuropathogenèse, la détection et la caractérisation de mutations atténuantes présentes et pouvant conduire à des vaccins atténués efficaces, et l'achèvement presque total de la séquence génomique de l'ADN du virus. Cette revue de la littérature, qui fait suite à un article préparé pour le symposium de Budapest, Hongrie, sur la maladie d'Aujeszky (1993), va résumer ces développements récents, et faire une mise à jour, pour le lecteur, des recherches menées dans ce domaine.

maladie d'Aujeszky / pseudorabies virus / glycoprotéine / pathogenèse moléculaire 
Table of contents

1. Introduction

2. Taxonomy

3. The virion

3.1. Genome

3.2. Capsid..

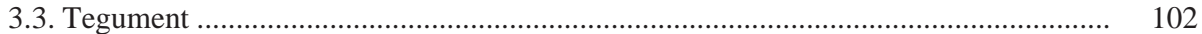

3.4. Envelope ............................................................................... 102

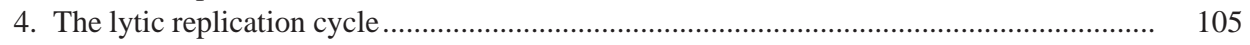

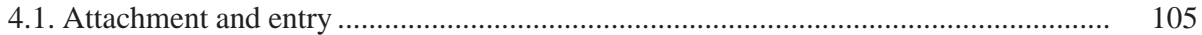

4.2. Intranuclear events ......................................................................................... 107

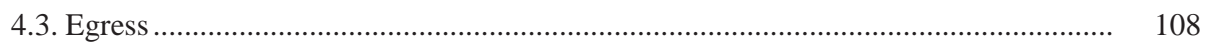

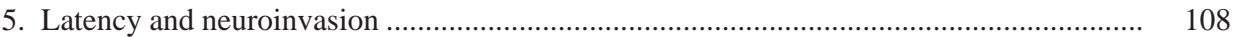

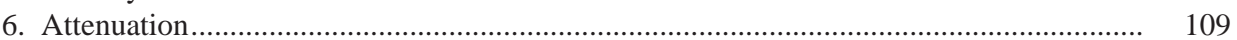

\section{INTRODUCTION}

Since the last "state of the art" review [64], much time has passed. In the meantime, Aujeszky's disease (AD) and its causative agent, pseudorabies virus (PrV), have become "endangered" in several parts of the world. This result is mainly based on the successful development and use of marker vaccines which allow a serologic differentiation between infected and vaccinated animals. Several milestones have been set by PrV researchers: the very first official approval for use of a genetically engineered live vaccine [48], the development of the concept of marked vaccines [66,90], and the first approval for the use of a genetically engineered live vaccine in the European Community [79]. In this review, the major focus will be on PrV as a fascinating pathogen whose understanding at a molecular level has not only helped to combat and eventually hopefully eradicate the disease but has also greatly contributed to our understanding of alphaherpesvirus biology.

\section{TAXONOMY}

PrV belongs to the Alphaherpesvirinae subfamily of the Herpesviridae. It has been found, by comparison of deduced amino acid sequences of homologous proteins, to be most closely related to bovine herpesvirus 1 (BHV-1) and equine herpesvirus 1 (EHV-1), and also to varicella-zoster virus (VZV) [59]. This prompted its assignment to the Varicellovirus genus within the Alphaherpesviruses. Alphaherpesviruses are distinguished by their rapid lytic growth in cell culture, their neurotropism, their latency in neurons and their broad host range. All these features are particularly pronounced in $\mathrm{PrV}$ and will be covered in this review. In spite of its broad host range which includes nearly all mammals except higher primates and humans, as well as other vertebrate species and cells in culture from various warm- and cold-blooded animals (Riebe et al., unpublished), the pig is the only host which is able to survive a productive infection and serve as a virus reservoir. This means that eliminating the virus from the porcine population can ultimately lead to eradication of the disease.

\section{THE VIRION}

Like all herpes virions, the $\operatorname{PrV}$ virion is composed of a nucleoprotein core which contains the genome, an icosahedral capsid of 162 capsomers, a proteinaceous tegument, and a lipid bilayer envelope derived from cellular membranes which contains virally encoded (glyco)proteins. Figure 1 


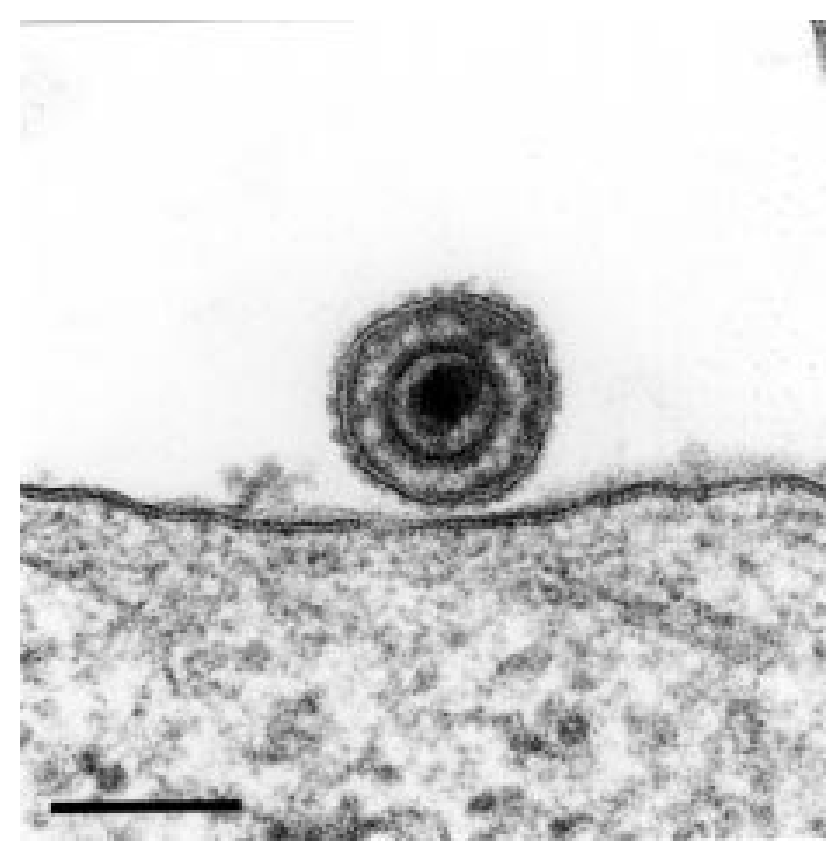

Figure 1. Electron micrograph of a $\mathrm{PrV}$ virion attached to a bovine kidney cell (MDBK) in culture. Bar: $150 \mathrm{~nm}$. (Picture courtesy of Dr. Harald Granzow, Friedrich-Loeffler-Institutes, Insel Riems, Germany).

shows an electron micrograph of a PrV virion attached to a bovine kidney cell [36].

\subsection{Genome}

The genome of PrV consists of a doublestranded linear DNA of approximately $150 \mathrm{kbp}$. The complete sequence of the genomic DNA has not yet been determined, primarily because the high content of $\mathrm{G}+\mathrm{C}$ nucleotides of $73 \%$ [6] renders sequencing laborious and costly. However, approximately $90 \%$ of the sequence has been elucidated and only one major gap in sequence information remains which, in analogy to other fully sequenced herpesvirus genomes and partial sequence information from $\operatorname{PrV}$, probably contains the homologues of the UL31 to UL37 genes of herpes simplex virus 1 (HSV-1). A summary is shown in Figure 2. It should be noted that the sequences are derived from several different PrV strains and mostly come in "bits and pieces".

The genome consists of a long $\left(\mathrm{U}_{\mathrm{L}}\right)$ and short unique region $\left(\mathrm{U}_{\mathrm{S}}\right)$, the latter being bracketed by inverted repeats. So far, three origins of replication which conform to the alphaherpesvirus consensus sequence have been mapped in the repeats $(2 \mathrm{x})$ (Fuchs et al., unpublished) and middle of the unique long region [50]. Another replication origin with apparently unique features resides at the left end of the genome [55]. Interestingly, within the PrV genome an inversion of ca. $40 \mathrm{kbp}$ is present which encompasses the UL27 to UL44 genes $[6,9,25]$. The biological significance of this genomic rearrangement is unclear. However, it is interesting that a similar inversion has also been detected in the only distantly related avian alphaherpesvirus infectious laryngotracheitis virus [99]. 


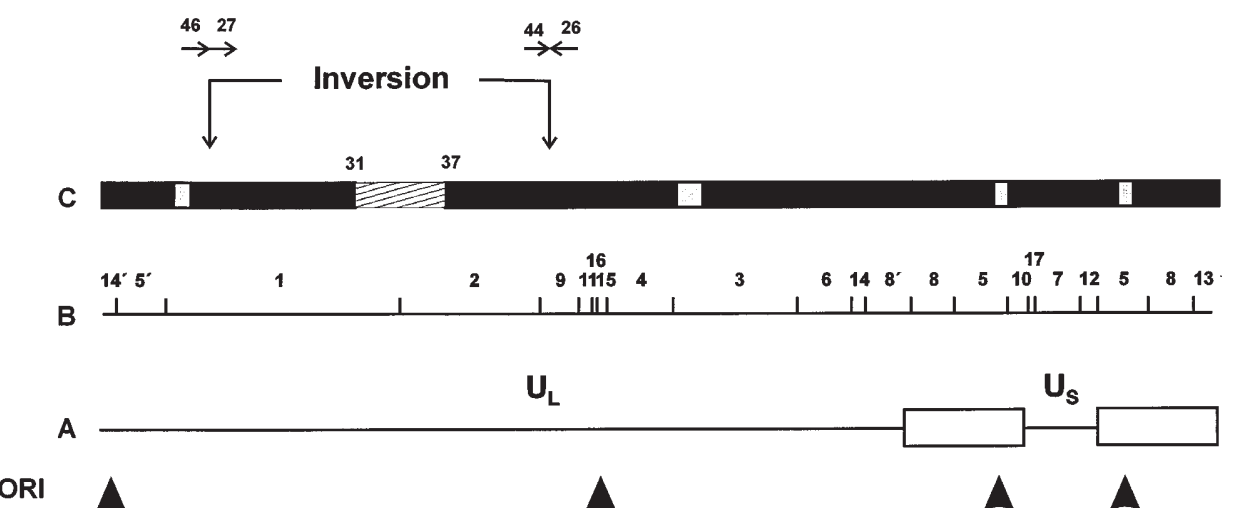

Figure 2. The PrV genome. In (A) the division of the genome into a unique long $\left(\mathrm{U}_{\mathrm{L}}\right)$ and unique short $\left(U_{S}\right)$ region by inverted repeats (open boxes) is shown. Arrows denote identified origins of replication. In (B) the Bam HI restriction fragment map of the PrV strain Ka is depicted. Those areas of the viral genome for which sequence information is available are designated in $(\mathrm{C})$ by closed boxes. Shaded areas denote parts of the genome in which sequence information is present in the author's laboratory but not yet published. Only one gap remains, indicated by the hatched area, which contains the open reading frames homologous to the UL31 to UL37 genes of HSV.

A list of identified PrV genes and (partially putative) functions of the encoded proteins is shown in Table I. Approximately half of the alphaherpesvirus genes are considered as "nonessential", that is they are dispensable for viral replication, at least in cell culture.

\subsection{Capsid}

Studies on capsid architecture have mainly been performed using HSV-1. However, the morphological similarity of herpesvirus capsids and the homology of capsid components indicates common principles. The alphaherpesvirus capsid is composed of products of the UL18 (part of "triplex" structures between capsomers), UL19 (major capsid protein which forms the hexon and penton capsomers), UL26 (scaffold, protease), UL26.5 (scaffold), UL35 (tips of hexons) and UL38 (triplex) genes [69]. The capsid is formed around a scaffolding structure which is proteolytically cleaved, and lost concomitant with incorporation of the genomic DNA into the preformed capsid. In PrV, homologues to the UL18, UL19, UL26, UL26.5 and UL38 genes of HSV-1 have been detected. The UL35 gene most likely resides in the not yet sequenced region.

\subsection{Tegument}

Little is known about the composition and possible structure of the tegument. In electron micrographs it appears as an electron-dense amorphous structure which lies between capsid and envelope. Several proteins of HSV-1 have been identified as tegument components and homologues have also been found in PrV (see Tab. I).

\subsection{Envelope}

The PrV envelope is derived from intracellular membranes of vesicles in the transGolgi area [36,94]. The envelope contains virally encoded proteins, most of which are modified by addition of carbohydrate side chains and are, thus, designated as glyco- 
Table I. PrV genes and proteins.

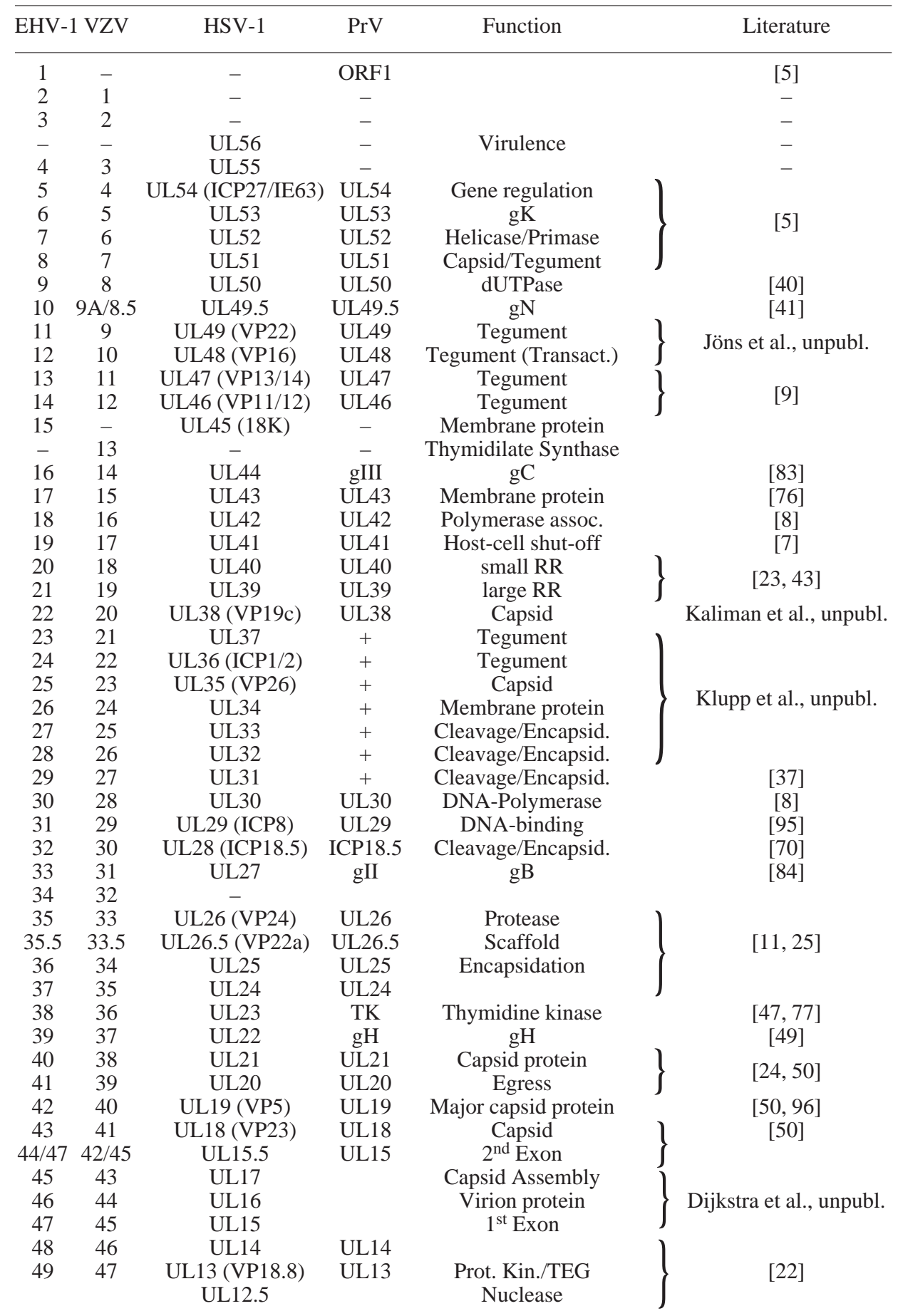


Table I. Continued.

\begin{tabular}{|c|c|c|c|c|c|}
\hline \multicolumn{2}{|c|}{ EHV-1 VZV } & \multirow{2}{*}{$\begin{array}{l}\text { HSV-1 } \\
\text { UL12 }\end{array}$} & \multirow{2}{*}{$\begin{array}{c}\text { PrV } \\
\text { UL12 }\end{array}$} & \multirow{2}{*}{$\begin{array}{c}\text { Function } \\
\text { Alk. Nuclease }\end{array}$} & \multirow{2}{*}{$\begin{array}{c}\text { Literature } \\
{[38]}\end{array}$} \\
\hline 50 & 48 & & & & \\
\hline 51 & 49 & UL11 & UL11 & Membrane protein & \multirow{5}{*}{ [29] } \\
\hline 52 & 50 & $\begin{array}{l}\text { UL10 } \\
\text { UI } 95\end{array}$ & $\begin{array}{l}\text { UL10 } \\
\text { UI } 95\end{array}$ & $\mathrm{gM}$ & \\
\hline 53 & 51 & $\begin{array}{l}\text { UL9.5 } \\
\text { UL9 }\end{array}$ & $\begin{array}{l}\text { UL9.5 } \\
\text { UL9 }\end{array}$ & Ori-binding & \\
\hline & & UL8.5 & & Ori-binding & \\
\hline 54 & 52 & UL8 & UL8 & Helicase/Primase & \\
\hline 55 & 53 & UL7 & UL7 & & \multirow{2}{*}[29,71]{} \\
\hline 56 & 54 & UL6 & UL6 & Capsid & \\
\hline 57 & 55 & UL5 & UL5 & Helicase/Primase & \multirow{2}{*}[20]{} \\
\hline 58 & 56 & UL4 & UL4 & & \\
\hline 59 & 57 & & UL3.5 & Egress & \multirow{2}{*}{ [19] } \\
\hline 60 & 58 & UL3 & UL3 & Membrane? & \\
\hline 61 & 59 & UL2 & UL2 & Uracil-Glycosylase & \\
\hline 62 & 60 & UL1 & UL1 & $\mathrm{gL}$ & {$[19,51]$} \\
\hline 63 & 61 & $\begin{array}{c}\text { IE110 (ICP0) } \\
\gamma 34.5\end{array}$ & $\begin{array}{c}\text { EP0 } \\
-\end{array}$ & $\begin{array}{l}\text { Gene regulation } \\
\text { Virulence }\end{array}$ & [15] \\
\hline 64 & 62 & IE175 (ICP4) & IE180 & Gene regulation & [14] \\
\hline 65 & 63 & US1 (IE68/ICP22) & $\mathrm{RSp} 40$ & Gene regulation & [97] \\
\hline 66 & 64 & US10 & - & Capsid/Tegument & \\
\hline 67 & - & - & - & & \\
\hline 68 & - & US2 & $28 \mathrm{~K}$ & Membrane protein & [91] \\
\hline 69 & 66 & US3 & PK & Protein Kinase & {$[91,98]$} \\
\hline 70 & - & US4 & $\mathrm{gX}$ & $\mathrm{gG}$ & [81] \\
\hline \multirow[t]{2}{*}{71} & - & - & - & - & \\
\hline & - & US5 & - & $\mathrm{gJ}$ & \\
\hline 72 & - & US6 & gp50 & $\mathrm{gD}$ & [75] \\
\hline 73 & 67 & US7 & gp63 & $\mathrm{gI}$ & \multirow{3}{*}[73]{} \\
\hline 74 & 68 & US8 & $\mathrm{gI}$ & $\mathrm{gE}$ & \\
\hline 75 & - & US8.5 & - & Nucleoli-assoc. & \\
\hline 76 & 65 & US9 & $11 \mathrm{~K}$ & Membrane protein & \multirow[t]{3}{*}{ [72] } \\
\hline - & - & US11 & - & Nucleic acid binding & \\
\hline- & - & US12 (IE12/ICP47) & - & TAP-blockade & \\
\hline
\end{tabular}

Genes in PrV are indicated compared to their counterparts in EHV-1, VZV and HSV-1. Designation of EHV-1 genes is according to [88], that of VZV genes is according to [18], that of HSV-1 genes according to [60,61] . PrV genes that have been completely sequenced are named as in their first description, mostly according to their HSV-1 counterparts. "+" indicates that partial sequence information is available. "-" indicates absence of gene. Information about function of the gene products in any of the viruses is also indicated.

proteins. In PrV, eleven glycoproteins have so far been described (Tab. II) which have been designated according to the unified nomenclature for herpesvirus glycoproteins as $\mathrm{gB}, \mathrm{gC}, \mathrm{gD}, \mathrm{gE}, \mathrm{gG}, \mathrm{gH}, \mathrm{gI}, \mathrm{gK}, \mathrm{gL}, \mathrm{gM}$, and $\mathrm{gN}$. $\mathrm{gB}$ forms a homodimeric complex, and $\mathrm{gE} / \mathrm{gI}, \mathrm{gH} / \mathrm{gL}$, and $\mathrm{gM} / \mathrm{gN}$ are present in heterooligomeric forms, presumably as heterodimers. All of these glycoproteins are constituents of the viral envelope except $\mathrm{gG}$, which is abundantly produced during
PrV infection and released into the medium. Other putative nonglycosylated membrane proteins are the products of the UL3, UL11, UL20, UL34, and UL43 genes. Interestingly, the PrV genome does not contain a UL45 homologous gene, at least not at a colinear position, which specifies a membrane protein in HSV [17]. The Us9 protein of PrV has also recently been shown to represent a membrane protein [10]. 


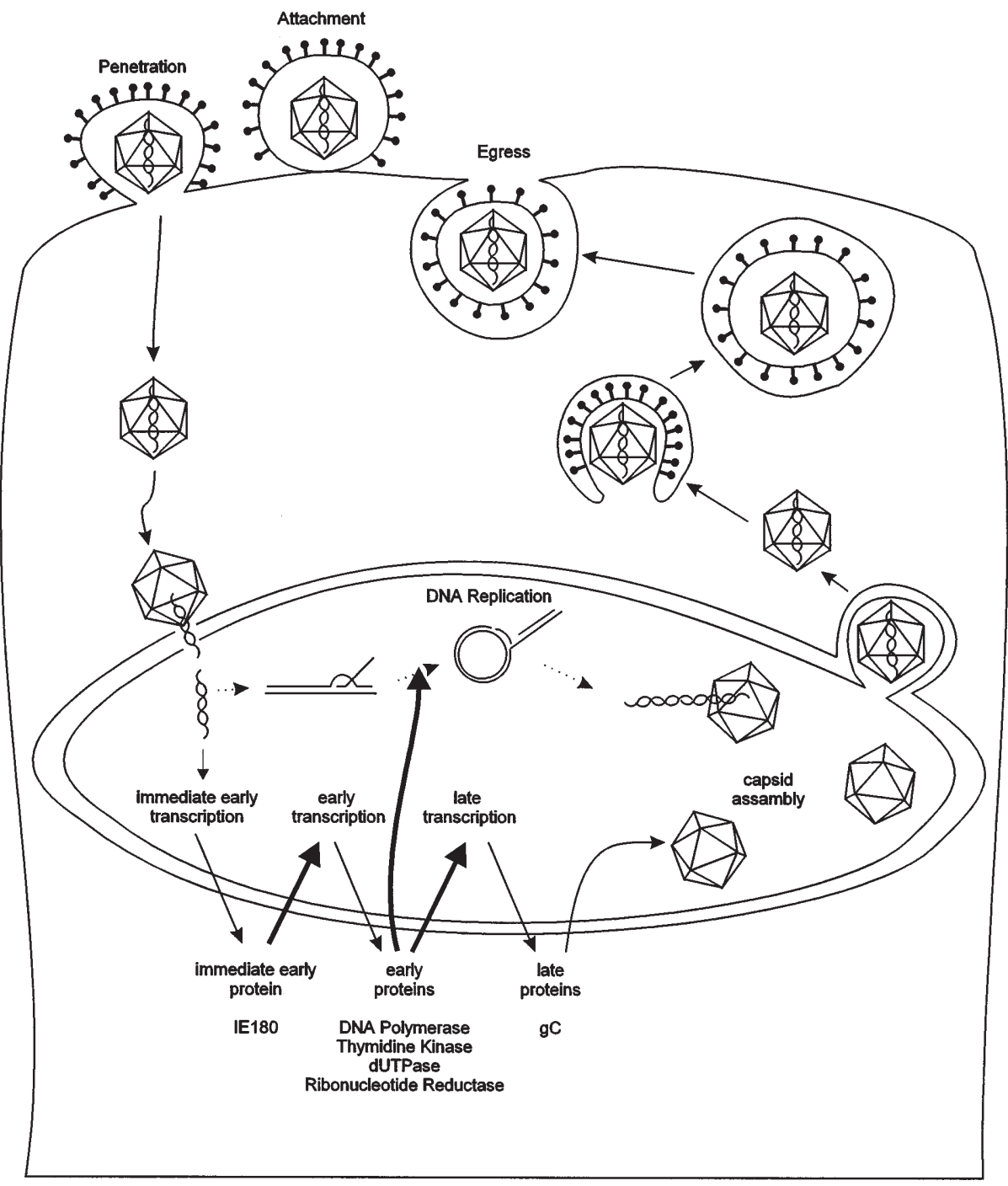

Figure 3. The PrV replication cycle.

\section{THE LYTIC REPLICATION CYCLE}

A diagram depicting the different steps in the PrV replication cycle is shown in Figure 3.

\subsection{Attachment and entry}

Infection of cells by herpesviruses is initiated by attachment of free virions to target cells followed by fusion of the virion envelope and the cellular cytoplasmic membrane 
Table II. Properties of pseudorabies virus glycoproteins.

\begin{tabular}{|c|c|c|c|c|c|c|c|}
\hline Designation $^{(a)}$ & Gene $^{(b)}$ & Essential & $\begin{array}{c}\text { Virion } \\
\text { component }\end{array}$ & Attachment & Penetration & $\begin{array}{l}\text { Cell-cell } \\
\text { spread }\end{array}$ & $\begin{array}{c}\text { Neuronal } \\
\text { spread }\end{array}$ \\
\hline gB (gII) & UL27 & + & + & - & $+^{(\mathrm{c})}$ & + & + \\
\hline gC (gIII) & UL44 & - & + & {$[+]^{(d)}$} & - & - & - \\
\hline $\mathrm{gD}(\mathrm{gp} 50)$ & US6 & + & + & {$[+]$} & + & - & - \\
\hline $\mathrm{gE}(\mathrm{gI})$ & US8 & - & + & - & - & {$[+]$} & {$[+]$} \\
\hline $\mathrm{gG}(\mathrm{gX})$ & US4 & - & - & - & - & - & - \\
\hline $\mathrm{gH}$ & UL22 & + & + & - & + & + & + \\
\hline gI (gp63) & US7 & - & + & - & - & {$[+]$} & {$[+]$} \\
\hline $\mathrm{gK}$ & UL53 & + & + & - & - & + & ?(e) \\
\hline $\mathrm{gL}$ & UL1 & + & + & - & + & + & $?$ \\
\hline $\mathrm{gM}$ & UL10 & - & + & - & - & {$[+]$} & - \\
\hline $\mathrm{gN}$ & UL49.5 & - & + & - & {$[+]$} & - & - \\
\hline
\end{tabular}

(a) The old nomenclature of PrV glycoproteins has been added in parentheses.

(b) Gene designation according to the HSV-1 homologue.

(c) + indicates an essential function.

(d) $[+]$ indicates a nonessential or modulating function.

(e) ?: no information available.

[63]. In both processes, the interaction between virion envelope glycoproteins and cellular surface components acting as virus receptors is critical. The first contact between $\mathrm{PrV}$ and the target cell is made by interaction of virion $\mathrm{gC}$ with heparan sulfate proteoglycans at the cell surface. This primary, relatively labile interaction converts into a stable binding which is mediated by interaction of $\mathrm{gD}$ with its cellular receptor [44]. Cellular alphaherpesvirus gD receptors have only recently been identified and proteins mediating PrV entry into otherwise relatively resistant chinese hamster ovary $(\mathrm{CHO})$ cells belong to the poliovirusreceptor family $[35,93]$. There may, however, be more receptors for PrV than those hitherto identified which is indicated by the fact that $\mathrm{CHO}$ cells are still infectable by PrV even in the absence of the gD receptors [69a] and that a gD-deficient mutant of PrV can infect cells via an alternate receptor [85]. Nevertheless, two viral glycoproteins, $\mathrm{gC}$ and $\mathrm{gD}$, and two cellular groups of receptors, heparan sulfate proteoglycans and poliovirus-receptor related proteins, are involved in PrV attachment. Interestingly, $\mathrm{gC}$ is a nonessential protein, whereas $\mathrm{gD}$ is normally essential but can become dis- pensable after selection in cell culture [85]. Recently, a PrV mutant has been selected which is infectious even in the absence of both attachment proteins, gC and gD [45], pointing to the presence of other yet unknown PrV attachment proteins.

For entry, the cellular cytoplasmic membrane and the viral envelope have to be in tight contact to fuse. For this fusion process to occur, at least four viral glycoproteins are required: $\mathrm{gB}, \mathrm{gH} / \mathrm{gL}$, and $\mathrm{gD}$ [63]. Absence of either of these glycoproteins in engineered viral mutants renders these viruses incapable to fuse. The molecular mechanisms by which these proteins mediate fusion are, however, still unclear. It is interesting, though, that at least the most highly conserved gB glycoproteins show partial cross complementation between different alphaherpesviruses which is indicative of a common mechanism of membrane fusion at least in this subfamily [80]. It should also be noted that $\mathrm{gB}, \mathrm{gH}$, and $\mathrm{gL}$ belong to those viral proteins whose genes are conserved throughout the herpesvirus family.

After translocation of the nucleocapsid into the cytoplasm of the cell, it is transported to the nuclear membrane and locates 
adjacent to nuclear pores. This transport most likely occurs along microtubules [36, 87]. The capsid is invariably oriented towards the nuclear pore so that one vertex is juxtaposed to the pore complex (Fig. 3) [36]. The DNA presumably leaves the virion and enters the nucleus through this vertex.

\subsection{Intranuclear events}

The incoming linear DNA circularises and transcription starts in the nucleus. Herpesvirus transcription is regulated in a cascade-like fashion. First, immediate-early (ie) genes which encode regulatory proteins are expressed. Unlike most other herpesviruses, PrV contains only one gene which is expressed with immediate-early kinetics. This gene encodes IE180 which is homologous to the major immediate-early protein of HSV-1, ICP4 [14]. PrV homologues to other HSV-1 ie-genes are present in PrV such as EP0 (ICP0 in HSV), RSp40 (ICP22 in HSV) and UL54 (ICP27 in HSV). These PrV genes are, however, regulated as early (e) genes. No PrV homologue to the ICP47 ie-protein of HSV-1 has been detected.

IE180 is a potent transactivator of early genes which include those encoding proteins required for DNA replication and other enzymatic functions. Early genes are characterised as being expressed before DNA replication. PrV encodes a number of proteins with enzymatic activity (see Tab. I). The most notable is thymidine kinase, an enzyme which is nonessential for viral growth in tissue culture but required for neurovirulence [48,62; see also below], as are dUTPase [42] and ribonucleotide reductase [23].

Replication of the viral genome requires the presence of the products of the UL5 (helicase), UL8 (helicase/primase), UL9 (origin of replication-binding protein), UL29 (major DNA binding protein), UL30 (DNApolymerase), UL42 (polymerase-associated protein) and UL52 (primase) genes [8]. They are needed for recognition of the site for initiation of DNA synthesis, for unwinding the supercoiled DNA, melting the double-helix, and synthesis of the complementary leading and lagging strands. Herpesvirus DNA replication proceeds by a rolling-circle mechanism leading to long head-to-tail concatemeric DNA molecules which need to be cleaved into unique length genomes before or during packaging into capsids. A large proportion of intranuclear viral DNA is present in those high molecular weight concatemeric structures.

Lastly, late genes specify several capsid and envelope components, for example $\mathrm{gC}$. It must be stressed, however, that the differentiation into these three kinetic classes is not absolute and several exceptions have been described (for example, a number of early-late genes whose expression starts before DNA replication but which reach their maximum expression levels only after DNA replication has begun).

After synthesis in the cytoplasm, capsid proteins enter the nucleus and form the basis for capsid assembly. This process is autocatalytic and requires only the respective capsid components [69]. In electron micrographs, intranuclear crescent shaped capsids can be observed indicating a step-bystep addition of capsomers to the nascent capsid precursor [36]. Intranuclear capsids are observed in three forms: with an inner scaffold structure, without a scaffold and with DNA, and without a scaffold and without DNA [67]. The latter are presumably the result of abortive DNA encapsidation attempts and are dead-end products. The products of the UL6, UL15, UL17, UL25, UL28, UL31, UL32 and UL33 genes [56] are involved in cleavage-encapsidation of concatemeric HSV-1 DNA. The UL28 gene product has also been described to be essential for capsid maturation in PrV [67]. 


\subsection{Egress}

Full capsids leave the nucleus by budding through the inner nuclear membrane. This first viral envelope appears "smooth" under the electron microscope which indicates the absence of (mature) glycoproteins. Also, virions in the perinuclear space lack or contain only very little tegument [36]. Virions leave the perinuclear space by fusion of the primary envelope with the outer nuclear membrane resulting in the release of naked capsids into the cytoplasm. A secondary envelopment process then takes place in the trans-Golgi area in which capsids bud into lamellae and vesicles of the trans-Golgi [36, 94]. Now, tegument is included and the secondary envelope clearly contains spike projections consisting of viral glycoproteins. The PrV UL3.5 gene product is essential for this process [33]. The net result of this budding event is the presence of a complete virus particle within a vesicle. These vesicles then move to the cytoplasmic membrane (a process which is blocked in the absence of the UL20 gene product) [34], fuse with the cytoplasmic membrane, and release the virus particle into the extracellular space. It is puzzling why released virions do not immediately re-enter the cell they have just left. Our data indicate that $\mathrm{gK}$ plays an important role in inhibition of re-fusion [53].

\section{LATENCY AND \\ NEUROINVASION}

Despite intensive efforts, the molecular basis for alphaherpesvirus latency is still largely unknown. In PrV, latently infected pigs are a constant danger for reactivation and virus shedding and thus for spreading of the virus in a susceptible population. Latency is defined as a status in which viral DNA persists but infectious virus is not produced. It is now common knowledge that during latency, viral gene expression is restricted to transcription of a distinct part of the viral genome into the so-called latency associated transcripts or LATs [78]. In HSV, these LATs exhibit antisense orientation to the mRNA for the regulatory immediateearly protein, ICP0. LAT expression in HSV is, however, not required for establishment of latency but may under certain circumstances play a role in reactivation.

A spliced and polyadenylated RNA, designated as the large latency transcript of $8.5 \mathrm{~kb}$, is expressed during PrV latency under control of a specific promotor, antiparallel to the IE180 and EP0 genes [15]. Whether this mRNA encodes any functional protein is unclear at present (reviewed in [30]).

Major sites of PrV latency are the trigeminal ganglion (TG), the olfactory bulb, and the tonsil. In these organs, viral DNA can be detected in the absence of infectious virus production, and LAT transcription could also be demonstrated by highly sensitive methods such as RT-PCR [16]. Presumably, after oronasal infection, PrV first replicates in the epithelial tissues and may also directly enter nerve endings of sensory neurons in the nasopharynx. After a first round of replication in the epithelia, progeny virus is abundantly produced leading to an increased infection of primary neurons.

Interestingly, there appears to be a correlation between precolonisation of trigeminal ganglia with PrV and failure of a superinfecting strain to become latent itself. This indicates that the number of neurons in which latency will be established is limited and that, probably, an already "occupied" neuron resists superinfection. Whether this interference requires a viral function or is dependent on cellular factors is unknown. It may, however, be deduced that attenuated live vaccine strains with a high potential for establishment of latency may prevent superinfecting wildtype strains from becoming latent [86].

Recently, the proteins which are required for neuroinvasion of PrV were analysed in detail. Several studies in mice, rats, and pigs 
have indicated that one of the key proteins in neuroinvasion is glycoprotein $\mathrm{E}[2,3,12$, $13,31]$. Deletion of this protein strongly attenuates PrV (see also below). Absence of $\mathrm{gE}$ does not impair primary viral replication in the nasal epithelium after intranasal infection of mice or pigs [2, 3, 54]. It is also not required for the virus to enter primary neurons. Transsynaptic transfer to second order neurons is, however, severely inhibited, resulting in a dramatic restriction in neuroinvasion. gE, and to a lesser extent $\mathrm{gI}$, are the predominant nonessential glycoproteins exhibiting this dramatic phenotype [32]. Other proteins which are required for cell-to-cell spread in culture are also essential for neuronal spread in the animal. These include $\mathrm{gB}$ and $\mathrm{gH}$ [1]. As in cell culture, $\mathrm{gD}$ is not required for transsynaptic transfer but is essential for entry into primary target cells. Thus, phenotypically gD-complemented $\mathrm{gD}^{-} \mathrm{PrV}$ invades the central nervous system after primary replication, and is virulent in mice [1].

The specific transneuronal transmission properties of PrV have sparked neuroanatomists to use this virus for tracing interconnecting neuronal circuits [32, 57, 89]. Several PrV mutants lacking gE which exhibit a restricted propagation in the CNS have thus been used. Visualisation of cells infected by mutant PrV has been facilitated by the insertion of marker genes expressing easily identifiable proteins such as $\beta$-galactosidase or green fluorescent protein [65]. Most notably, tracing studies using pairs of genetically and phenotypically differentiable PrV mutants have allowed simultaneous tracing of different neuronal pathways [39].

\section{ATTENUATION}

The obvious success of the AD eradication programs is primarily based on the efficacy and safety of the modified live vaccines used. For containment of AD and suppression of symptoms, live vaccines, which had been attenuated by classical means such as extensive passaging in vitro or selection for drug-resistance or temperature-sensitivity, have been used for a long time. One of these strains is represented by the vaccine strain Bartha, now a "classic" within the PrV vaccine repertoire [4].

Molecular analysis of this strain for more than 15 years finally led to the identification of the genomic mutations responsible for attenuation. PrV Bartha contains a large deletion within the $U_{S}$ region of the viral genome which encompasses part of the gI, all of the gE and Us9, and part of the Us2 genes $[58,74]$. It also carries mutations within the $\mathrm{gC}$ gene which include an alteration in the aminoterminal signal sequence resulting in inefficient intracellular translocation and incorporation of this protein into the viral envelope [82]. Lastly, point mutations within the UL21 gene, whose product is involved in capsid formation, contribute to the avirulence of PrV Bartha [52]. Restoration of all three defects is required for recovery of the virulent phenotype. Thus, PrV Bartha harbours three independent attenuating defects which explain its high safety (Fig. 4). Moreover, PrV Bartha is interesting in that it expresses an additional modified protein. The product of the UL10 gene is a protein conserved throughout the herpesviruses and its product has been identified as a nonessential glycoprotein, gM. Surprisingly, the Bartha UL10 gene contains mutations which abolish the single $\mathrm{N}$-glycosylation site for the protein so that Bartha's UL10 product is not glycosylated and, thus, cannot be named "g"M [26,27]. However, this mutation apparently does not influence virulence of this strain.

During the strive for combatting AD, genetic engineering methods were first used to develop attenuated strains by inactivating the gene encoding the thymidine kinase (TK) enzyme. In fact, one of these TK-negative strains became the very first genetically modified live vaccine licensed for use $[47,48]$. Another milestone was the licensing of a similar genetically modified strain 


\section{Mutations in PrV vaccine strain Bartha}

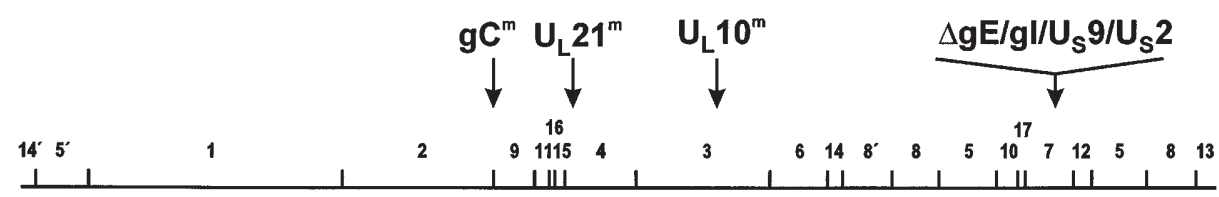

$\mathbf{U}_{\mathbf{L}}$

$\mathbf{U}_{\mathrm{s}}$

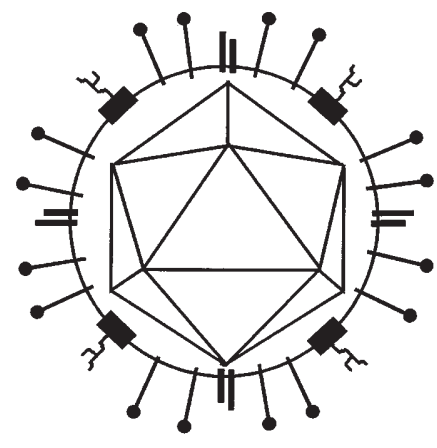

PrV WT

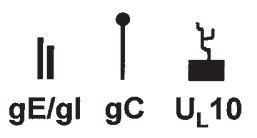

$\mathrm{gE} / \mathrm{gl} \mathrm{gC} \mathrm{U}_{\mathrm{L}} \mathbf{1 0}$

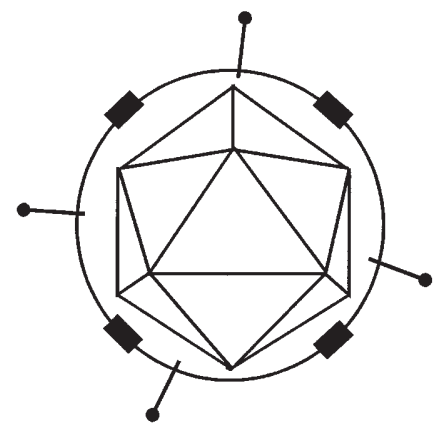

PrV Bartha

Figure 4. Mutations present in the genome of the PrV strain Bartha. The deletion in the $\mathrm{U}_{\mathrm{S}}$ region encompassing the gI, gE, Us9 and Us2 genes, and the mutations in the $\mathrm{gC}$, UL10, and UL21 genes are indicated. The consequences of these mutations on the envelope structure of PrV Bartha are depicted schematically below in comparison with PrV wildtype (WT).

for use in western Europe [79]. As mentioned above, PrV Bartha naturally lacks $\mathrm{gE}$ which was first demonstrated by Mettenleiter et al. [66]. Based on this finding, van Oirschot et al. [90] developed a serological test which is able to distinguish between animals which carry antibodies against $\mathrm{gE}$ (after a field virus infection) and those which lack antibodies against $\mathrm{gE}$ but carry antibodies against other PrV glycoproteins (after vaccination). Thus the concept of the "marked" vaccine emerged. The success of the AD eradication programs based on these marked vaccines testifies for the applicability of this concept. In the meantime, deletions of the gE- but also of the $\mathrm{gC}$ - and gG-genes which can also be used as markers, have been primarily introduced by genetic engineering methods. PrV therefore serves as an excellent example of how molecular biology and basic science profoundly influence practical animal disease control.

Besides TK, RR, and gE [23, 46, 48, 68], inactivation of several other PrV genes has been shown to result in attenuation of the virus. In fact, inactivation of most genes whose products are nonessential for viral replication in cell culture somehow 
Table III. Virulence-modulating nonessential genes and proteins of PrV.

\begin{tabular}{lcc}
\hline Gene & Protein & Category \\
\hline UL10 & Glycoprotein gM & Envelope Glycoprotein \\
UL13 & Protein kinase & Enzyme \\
UL21 & Capsid Protein \\
UL23 & Thymidine kinase & Enzyme \\
UL39/40 & Ribonucleotide Reductase & Enzyme \\
UL44 & Glycoprotein gC & Envelope Glycoprotein \\
UL50 & dUTPase & Enzyme \\
US3 & Protein kinase & Enzyme \\
US7 & Glycoprotein gI & Envelope Glycoprotein \\
US8 & Glycoprotein gE & Envelope Glycoprotein \\
\hline
\end{tabular}

decreases PrV virulence. A list of published examples is shown in Table III. It can be concluded that nowadays with genetic engineering techniques, a number of possible target genes are accessible for the construction of viruses with different attenuated properties [21, 28, 42, 48].

Lastly, PrV has been developed into a powerful vector system for expression of heterologous genes. Although none of these vectors has so far attained the status of practical application, PrV-classical swine fever recombinants [92] may indeed help fight two devastating pig diseases at the same time with a vaccine which has the benefit of being "marked" for AD (by the absence of $\mathrm{gE}$ ) and classical swine fever (by the sole presence of CSFV-E2). For insertion of foreign genes, numerous insertion sites have been described which may also be used for integration of several different heterologous genes.

\section{ACKNOWLEDGMENTS}

Work in the author's laboratory has been supported by the Deutsche Forschungsgemeinschaft, the European Union, and Intervet International B.V. I thank Barbara Klupp, Klaus Osterrieder and Ines Jakobi for help in preparing this manuscript, and Jerg Schmidt for the artwork.

\section{REFERENCES}

[1] Babic N., Mettenleiter Th.C., Flamand A., Ugolini G., Role of essential glycoproteins gII and gp50 in transneuronal transfer of pseudorabies virus from the hypoglossal nerves of mice, J. Virol. 67 (1993) 4421-4426.

[2] Babic N., Mettenleiter Th.C., Ugolini G., Flamand A., Coulon P., Propagation of pseudorabies virus in the nervous system of the mouse after intranasal inoculation, Virology 204 (1994) 616-625.

[3] Babic N., Klupp B.G., Brack A., Mettenleiter Th.C., Flamand A., Deletion of glycoprotein $\mathrm{gE}$ reduces the propagation of pseudorabies virus in the nervous system of the mouse after intranasal inoculation, Virology 219 (1996) 279-284.

[4] Bartha A., Experimental reduction of virulence of Aujeszky's disease virus (in Hungarian), Magyar Állatorvosok Lapja 16 (1961) 42-45.

[5] Baumeister J., Klupp B.G., Mettenleiter Th.C., Pseudorabies virus and equine herpesvirus 1 share a nonessential gene which is absent in other herpesviruses and located adjacent to a highly conserved gene cluster, J. Virol. 69 (1995) 55605567.

[6] Ben-Porat T., Kaplan A.S., Molecular biology of pseudorabies virus, in: Roizman B. (Eds.), The Herpesviruses, Plenum Press, New York, 1985, pp. 105-173.

[7] Berthomme H., Jacquemont B., Epstein A., The pseudorabies virus host-shutoff homolog gene: nucleotide sequence and comparison with alphaherpesvirus protein counterparts, Virology 193 (1993) 1028-1032.

[8] Berthomme H., Monahan S.J., Parris D.S., Jacquemont B., Epstein A.L., Cloning, sequencing, and functional characterization of the two subunits of the pseudorabies virus DNA polymerase holoenzyme: evidence for specificity of interaction, J. Virol. 69 (1995) 2811-2818. 
9] Bras F., Dezélée S., Simonet B., Nguyen X., Vende P., Flamand A., Masse M.J., The left border of the genomic inversion of pseudorabies virus contains genes homologous to the UL46 and UL47 genes of herpes simplex virus type 1, but no UL45 gene, Virus Res. 60 (1999) 29-40.

[10] Brideau A.D., Banfield B.W., Enquist L.W., The US9 gene product of pseudorabies virus, an alphaherpesvirus, is a phosphorylated, tail-anchored type II membrane protein, J. Virol. 72 (1998) 4560-4570.

[11] Camacho A., Tabarés E., Characterization of the genes, including that encoding the viral proteinase, contained in BamHI restriction fragment 9 of the pseudorabies virus genome, J. Gen. Virol. 77 (1996) 1865-1874.

[12] Card J.P., Pseudorabies virus replication and assembly in the rodent central nervous system, in: Kaplitt M., Loewy A.D. (Eds.), Viral Vectors, Academic Press, Inc., 1995, pp. 319-347.

[13] Card J.P., Levitt P., Enquist L.W., Different patterns of neuronal infection after intracerebral injection of two strains of pseudorabies virus, J. Virol. 72 (1998) 4434-4441.

[14] Cheung A.K., DNA nucleotide sequence analysis of the immediate-early gene of pseudorabies virus, Nucl. Acids Res. 17 (1989) 4637-4646.

[15] Cheung A.K., Cloning of the latency gene and the early protein 0 gene of pseudorabies virus, $\mathrm{J}$. Virol. 65 (1991) 5260-5271.

[16] Cheung A.K., Investigation of pseudorabies virus DNA and RNA in trigeminal ganglia and tonsil tissues of latently infected swine, Am. J. Vet. Res. 56 (1995) 45-50.

[17] Cockrell A.S., Muggeridge M.I., Herpes simplex virus 2 UL45 is a type II membrane protein, $\mathrm{J}$. Virol. 72 (1998) 4430-4433.

[18] Davison A.J., Scott J.E., The complete DNA sequence of varicella-zoster virus, J. Gen. Virol. 67 (1986) 1759-1816.

[19] Dean H.J., Cheung A.K., A 3' coterminal gene cluster in pseudorabies virus contains herpes simplex virus UL1, UL2, and UL3 gene homologs and a unique UL3.5 open reading frame, J. Virol. 67 (1993) 5955-5961.

[20] Dean H.J., Cheung A.K., Identification of the pseudorabies virus UL4 and UL5 (helicase) genes, Virology 202 (1994) 962-967.

[21] Dean H.J., Cheung A.K., A deletion at the $\mathrm{U}_{\mathrm{L}} / \mathrm{I}_{\mathrm{R}}$ junction reduces pseudorabies virus neurovirulence, J. Virol. 69 (1995) 1334-1338.

[22] DeWind N., Domen J., Berns A., Herpesviruses encode an unusual protein-serine/threonine kinase which is nonessential for growth in cultured cells, J. Virol. 66 (1992) 5200-5209.

[23] DeWind N., Berns A., Gielkens A., Kimman T., Ribonucleotide reductase-deficient mutants of pseudorabies virus are avirulent for pigs and induce partial protective immunity, J. Gen. Virol. 74 (1993) 351-359.
[24] De Wind N., Wagenaar F., Pol J., Kimman T., Berns A., The pseudorabies virus homolog of the herpes simplex virus UL21 gene product is a capsid protein which is involved in capsid maturation, J. Virol. 66 (1992) 7096-7103.

[25] Dezélée S., Bras F., Vende P., Simonet B., Nguyen X., Flamand A., Masse M.J., The BamHI fragment 9 of pseudorabies virus contains genes homologous to the UL24, UL25, UL26, and UL26.5 genes of herpes simplex virus 1, Virus Res. 42 (1996) 27-39.

[26] Dijkstra J., Mettenleiter Th.C., Klupp B.G., Intracellular processing of pseudorabies virus glycoprotein $\mathrm{M}(\mathrm{gM})$ : $\mathrm{gM}$ of strain Bartha lacks Nglycosylation, Virology 237 (1997) 113-122.

[27] Dijkstra J., Visser N., Mettenleiter Th.C., Klupp B.G., Identification and characterization of pseudorabies virus glycoprotein $\mathrm{gM}$ as a nonessential virion component, J. Virol. 70 (1996) 56845688.

[28] Dijkstra J., Gerdts V., Klupp B.G., Mettenleiter Th.C., Deletion of glycoprotein gM of pseudorabies virus results in attenuation for the natural host, J. Gen. Virol. 78 (1997) 2147-2151.

[29] Dijkstra J.M., Fuchs W., Mettenleiter T.C., Klupp B.G., Identification and transcriptional analysis of pseudorabies virus UL6 to UL12 genes, Arch. Virol. 142 (1997) 17-35.

[30] Enquist L.W., Infection of the mammalian nervous system by pseudorabies virus (PRV), Seminars in Virol. 5 (1994) 221-231.

[31] Enquist L.W., Circuit-specific infection of the mammalian nervous system, ASM News 61 (1995) 633-638

[32] Enquist L.W., Husak P.J., Banfield B.W., Smith G.A., Infection and spread of alphaherpesviruses in the nervous system, Advances in Virus Res. 51 (1999) 237-347.

[33] Fuchs W., Klupp B.G., Rziha H.-J., Mettenleiter Th.C., Identification and characterization of the pseudorabies virus UL3.5 protein, which is involved in virus egress, J. Virol. 70 (1996) 35173527.

[34] Fuchs W., Klupp B.G., Granzow H., Mettenleiter Th.C., The UL20 gene product of pseudorabies virus functions in virus egress, J. Virol. 71 (1997) 5639-5646.

[35] Geraghty R.J., Krummenacher C., Cohen G.H., Eisenberg R.J., Spear P.G., Entry of alphaherpesviruses mediated by poliovirus receptor-related protein 1 and poliovirus receptor, Science 280 (1998) 1618-1620.

[36] Granzow H., Weiland F., Jöns A., Klupp B., Karger A., Mettenleiter Th.C., Ultrastructural Analysis of the Replication Cycle of Pseudorabies Virus in Cell Culture: A Reassessment, J. Virol. 71 (1997) 2072-2082.

[37] Ho T.-Y., Hsiang C.-Y., Chang T.-J., Analysis of pseudorabies virus genes by cDNA sequencing, Gene 175 (1996) 247-251 
[38] Hsiang C.-Y., Ho T.Y., Chang T.-J., Identification of a pseudorabies virus UL12 (deoxyribonuclease) gene, Gene 177 (1996) 109-113.

[39] Jansen A., van Nguyen X., Karpitskiy V., Mettenleiter Th.C., Loewy A., Central command neurons of the sympathetic nervous system - neuroanatomical basis of the fight-or-flight response, Science, 270 (1995) 644-646.

[40] Jöns A., Mettenleiter Th.C., Identification and characterization of pseudorabies virus dUTPase, J. Virol. 70 (1996) 1242-1245.

[41] Jöns A., Granzow H., Kuchling R., Mettenleiter Th.C., The UL49.5 gene of pseudorabies virus (PrV) codes for an O-glycosylated structural protein of the viral envelope, J. Virol. 70 (1996) 1237-1241.

[42] Jöns A., Gerdts V., Lange E., Kaden V., Mettenleiter Th.C., Attenuation of dUTPase deficient pseudorabies virus for the natural host, Vet. Microbiol. 56 (1997) 47-54.

[43] Kaliman A.V., Boldogköi Z., Fodor I., Large and small subunits of the Aujeszky's disease virus ribonucleotide reductase: nucleotide sequence and putative structure, Biochim. Biophys. Acta 1219 (1994) 151-156.

[44] Karger A., Mettenleiter Th.C., Glycoproteins gIII and gp50 play dominant roles in the biphasic attachment of pseudorabies virus, 194 (1993) 654-664.

[45] Karger A., Schmidt J., Mettenleiter Th.C., Infectivity of a pseudorabies virus mutant lacking attachment glycoproteins C and D, J. Virol. 72 (1998) 7314-7348

[46] Kimman T., de Wind N., Oei-Lie N., Pol J., Berns A., Gielkens A., Contribution of single genes within the unique short region of Aujeszky's disease virus (suid herpesvirus type 1) to virulence, pathogenesis and immunogenicity, J. Gen. Virol. 73 (1992) 243-251.

[47] Kit S., U.S. Patent Application no. 4514497, 1985.

[48] Kit S., Kit M., Bartkoski M.J., Dees G., Genetically engineered pseudorabies virus vaccine with deletions in thymidine kinase and glycoprotein genes, Cold Spring Harbor Symposium Vaccines 87: Pseudorabies Vaccines (1987) 345-349.

[49] Klupp B., Mettenleiter Th.C., Sequence and expression of the glycoprotein $\mathrm{gH}$ gene of pseudorabies virus, Virology 182 (1991) 732-741.

[50] Klupp B., Kern H., Mettenleiter Th.C., The virulence-determining genomic Bam HI-fragment 4 of pseudorabies virus contains genes corresponding to the UL15 (partial), UL18, UL19, UL20, and UL21 genes of herpes simplex virus and a putative origin of replication, Virology 191 (1992) 900-908.

[51] Klupp B.G., Baumeister J., Karger A., Visser N., Mettenleiter Th.C., Identification and characterization of a novel structural glycoprotein in pseudorabies virus, gL, J. Virol. 68 (1994) 3868-3878.
[52] Klupp B.G., Lomniczi B., Visser N., Fuchs W., Mettenleiter Th.C., Mutations affecting the UL21 gene contribute to avirulence of pseudorabies virus vaccine strain Bartha, Virology 212 (1995) 466-473.

[53] Klupp B., Baumeister J., Dietz P., Granzow H., Mettenleiter Th.C., Pseudorabies virus glycoprotein $\mathrm{gK}$ is a structural component of virions involved in virus release but not required for entry, J. Virol. 72 (1998) 1949-1958.

[54] Kritas S.K., Pensaert M., Mettenleiter Th.C., Invasion and spread of single glycoprotein deleted mutants of Aujeszky's disease virus (ADV) in the trigeminal nervous pathway of pigs after intranasal inoculation, Vet. Microbiol. 40 (1994) 323-334.

[55] Kupershmidt S., de Marchi J., Lu Z., Ben-Porat T., Analysis of an origin of DNA replication located at the $\mathrm{L}$ terminus of the genome of pseudorabies virus, J. Virol. 65 (1991) 6283-6291.

[56] Lamberti C., Weller S.K., The herpes simplex virus type 1 cleavage/packaging protein, UL32, is involved in efficient localization of capsids to replication compartments, J. Virol. 72 (1998) 2463-2473.

[57] Loewy A.D., Pseudorabies virus: a transneuronal tracer for neuroanatomical studies, in: Kaplitt M., Loewy A.D. (Eds.), Viral Vectors, Academic Press, Inc., 1995, pp. 349-366.

[58] Lomniczi B., Watanabe S., Ben-Porat T., Kaplan A.S., Genetic basis of the neurovirulence of pseudorabies virus, J. Virol. 52 (1984) 198-205.

[59] McGeoch D.J., Cook S., Molecular phylogeny of the alphaherpesvirinae subfamily and a proposed evolutionary timescale, J. Mol. Biol. 238 (1994) 9-22.

[60] McGeoch D.J., Dolan A., Donald S., Rixon F.J., Sequence determination and genetic content of the short unique region of the genome of herpes simplex virus type 1, J. Molec. Biol. 181 (1985) $1-13$.

[61] McGeoch D.J., Dalrymple M.A., Davison A.J., Dolan A., Frame M.C., McNab D., Perry L.J., Scott J.E., Taylor. P., The complete DNA sequence of the long unique region in the genome of herpes simplex virus type 1, J. Gen. Virol. 69 (1988) 1531-1574.

[62] McGregor S., Easterday B.C., Kaplan A.S., BenPorat T., Vaccination of swine with thymidine kinase-deficient mutants of pseudorabies virus, Am. J. Vet. Res. 46 (1985) 1494-1497.

[63] Mettenleiter Th.C., Initiation and spread of $\alpha$-Herpesvirus infections, Trends Microbiol. 2 (1994) 2-4.

[64] Mettenleiter Th.C., Pseudorabies (Aujeszky's disease) virus: State of the art, August 1993, Acta Vet. Hung. 42 (1994) 153-177.

[65] Mettenleiter Th.C., Molecular properties of alphaherpesviruses used in neuronal pathway tracing, in: Kaplitt M., Loewy A.D. (Eds.), Viral Vectors, Academic Press, Inc., 1995, pp. 367-393. 
[66] Mettenleiter Th.C., Lukacs N., Rziha H.-J., Pseudorabies virus avirulent strains fail to express a major glycoprotein, J. Virol. 56 (1985) 307-311.

[67] Mettenleiter Th.C., Saalmüller A., Weiland F., Pseudorabies virus protein homologous to herpes simplex virus type 1 ICP18.5 is necessary for capsid maturation, J. Virol. 67 (1993) 1236-1245.

[68] Mettenleiter Th.C., Zsak L., Kaplan A, Ben-Porat T. Lomniczi B., Role of a structural glycoprotein of pseudorabies in virus virulence, J. Virol. 61 (1987) 4030-4032.

[69] Newcomb W.N., Homa F.L., Thomsen D.R., Trus B.L., Cheng N., Steven A., Booy F., Brown J.C., Assembly of the herpes simplex virus procapsid from purified components and identification of small complexes containing the major capsid and scaffolding proteins, J. Virol. 73 (1999) 42394250.

[69a]Nixdorf R., Schmidt J., Karger A., Mettenleiter T.C., Infection of chinese hamster ovary cells by pseudorabies virus, J. Virol. 73 (1999) 8019-8026.

[70] Pedersen N., Enquist L., The nucleotide sequence of a pseudorabies virus gene similar to ICP18.5 of herpes simplex virus type 1 , Nucleic Acids Res. 17 (1989) 3597.

[71] Pedersen N.E., Casey II J.T., Koslowski K.M., Shaver P.R., The UL6 locus of pseudorabies virus and its homology to oncogenic herpesviruses, Oncol. Rep. 5 (1998) 115-119.

[72] Petrovskis E., Post L., A small open reading frame in pseudorabies virus and implications for evolutionary relationships between herpesviruses, Virology 159 (1987) 193-195.

[73] Petrovskis E., Timmins J.G., Post L., Use of $\lambda$ gt11 to isolate genes for two pseudorabies virus glycoproteins with homology to herpes simplex virus and varicella-zoster virus glycoproteins, J. Virol. 60 (1986) 185-193.

[74] Petrovskis E.A., Timmins J.G., Gierman T.M., Post L.E., Deletions in vaccine strains of pseudorabies virus and their effect on synthesis of glycoprotein gp63, J. Virol. 60 (1986) 1166-1169.

[75] Petrovskis E., Timmins J.G., Armentrout M.A., Marchioli C.C., Yancy R.J., Post L.E., DNA sequence of the gene for pseudorabies virus gp50, a glycoprotein without N-linked glycosylation, J. Virol. 59 (1986) 216-223

[76] Powers L., Wilkinson K.S., Ryan P., Characterization of the prv43 gene of pseudorabies virus and demonstration that it is not required for virus growth in cell culture, Virology 199 (1994) 81-88.

[77] Prieto J., Hernàndez A.M., Tabarés E., Loss of pseudorabies virus thymidine kinase activity due to a single base mutation and amino acid substitution, J. Gen. Virol. 72 (1991) 1435-1439.

[78] Priola S.A., Stevens J.G., The 5' and 3' limits of transcription in the pseudorabies virus latency associated transcription unit, Virology 182 (1991) $852-856$.
[79] Quint W., Gielkens A., van Oirschot J., Berns A., Cuypers H.T., Construction and characterization of deletion mutants of pseudorabies virus: a new generation of "Live" vaccines, J. Gen. Virol. 68 (1987) 523-534.

[80] Rauh I., Weiland F., Fehler F., Keil G., Mettenleiter Th.C., Pseudorabies virus mutants lacking the essential glycoprotein gII can be complemented by glycoprotein gI of bovine herpesvirus 1, J. Virol. 65 (1991) 621-631.

[81] Rea T., Timmins J., Long G., Post L., Mapping and sequence of the gene for the pseudorabies virus glycoprotein which accumulates in the medium of infected cells, J. Virol. 54 (1985) 2129.

[82] Robbins A.K., Ryan J.P., Whealy M.E., Enquist L.W., The gene encoding the gIII envelope protein of pseudorabies virus vaccine strain Bartha contains a mutation affecting protein localization, J. Virol. 73 (1989) 250-258

[83] Robbins A.K., Watson R.J., Whealy M.E., Hays W.W., Enquist L.W., Characterization of a pseudorabies virus glycoprotein gene with homology to herpes simplex virus type 1 and type 2 glycoprotein C, J. Virol. 58 (1986) 339-347.

[84] Robbins A.K., Dorney D.J., Wathen M.W., Whealy M.E., Gold C., Watson R.J., Holland L.E., Weed S.D., Levine M., Glorioso J.C., Enquist L.W., The pseudorabies virus gII gene is closely related to the $\mathrm{gB}$ glycoprotein gene of herpes simplex virus, J. Virol. 61 (1987) 26912701.

[85] Schmidt J., Klupp B.G., Karger A., Mettenleiter Th.C., Adaptability in herpesviruses: glycoprotein D-independent infectivity of pseudorabies virus, J. Virol. 71 (1997) 17-24.

[86] Schang L.M., Kutish G.F., Osorio F.A., Correlation between precolonization of trigeminal ganglia by attenuated strains of pseudorabies virus and resistance to wild-type virus latency, J. Virol. 68 (1994) 8470-8476.

[87] Sodeik B., Ebersold M.W., Helenius A., Microtubule-mediated transport of incoming herpes simplex virus 1 capsids to the nucleus, J. Cell Biol. 136 (1997) 1007-1021.

[88] Telford E., Watson M., McBride K., Davison A., The DNA sequence of equine herpesvirus-1, Virology 189 (1992) 304-316.

[89] Ugolini G., Transneuronal tracing with alphaherpesviruses: a review of the methodology; in: Kaplitt M., Loewy A.D. (Eds.), Viral Vectors, Academic Press, Inc., 1995, pp. 293-317.

[90] van Oirschot J.T., Rziha H.J., Moonen P.J.L.M., Pol J.M.A., van Zaane D., Differentiation of serum antibodies from pigs vaccinated or infected with Aujesky's disease virus by a competitive enzyme immunoassay, J. Gen. Virol. 67 (1986) 1179-1182.

[91] van Zjil M., van de Gulden H., de Wind N., Gielkens A., Berns A., Identification of two genes in the unique short region of pseudorabies virus; 
comparison with herpes simplex virus and varicella-zoster virus, J. Gen. Virol. 71 (1990) 1747 1755 .

[92] van Zijl M., Wensvoort G., de Kluyver E., Hulst M., van der Gulden H., Gielkens A., Berns A., Moormann R., Live attenuated pseudorabies virus expressing envelope glycoprotein E1 of hog cholera virus protects swine against both pseudorabies and hog cholera, J. Virol. 65 (1991) 2761-2765.

[93] Warner M.S., Geraghty R.J., Martinez W.M., Montgomery R.I., Whitbeck J.C., Xu R., Eisenberg R.J., Cohen G.H., Spear P.G., A cell surface protein with herpesvirus entry activity (HveB) confers susceptibility to infection by mutants of herpes simplex virus type 1, herpes simplex virus type 2 , and pseudorabies virus, Virology 246 (1998) 179-189.

[94] Whealy M.E., Card J.P., Meade R.P., Robbins A.K., Enquist L.W., Effect of brefeldin A on alphaherpesvirus membrane protein glycosylation and virus egress, J. Virol. 65 (1991) 10661081 .
[95] Wu S.-L., Hsiang C.-Y., Ho T.-Y., Chang T.-J., Identification, expressing, and characterization of the pseudorabies virus DNA-binding protein gene and gene product, Virus Res. 56 (1998) 1-9.

[96] Yamada S., Imada T., Watanabe W., Honda Y., Nakajima-Iijima S., Shimizu Y., Sekikawa K., Nucleotide sequence and transcriptional mapping of the major capsid protein gene of pseudorabies virus, Virology 185 (1991) 56-66.

[97] Zhang G., Leader D.P., The structure of the pseudorabies virus genome at the end of the inverted repeat sequences proximal to the junction with the short unique region, J. Gen. Virol. 71 (1990) 2433-2441.

[98] Zhang G., Stevens R., Leader D.P., The protein kinase encoded in the short unique region of pseudorabies virus: description of the gene and identification of its product in virions and in infected cells, J. Gen. Virol. 71 (1990) 1757-1765.

[99] Ziemann K., Mettenleiter Th.C., Fuchs W., Gene arrangement within the unique long genome region of infectious laryngotracheitis virus is distinct from other alphaherpesviruses, J. Virol. 72 (1998) 847-852. 